Portland State University

PDXScholar

Sociology Faculty Publications and

Presentations

Sociology

$11-24-2020$

\title{
Enclosing Water: Privatization, Commodification, and Access
}

Daniel Jaffee

Portland State University, jaffee@pdx.edu

Follow this and additional works at: https://pdxscholar.library.pdx.edu/soc_fac

Part of the Demography, Population, and Ecology Commons, Family, Life Course, and Society

Commons, and the Rural Sociology Commons

Let us know how access to this document benefits you.

\section{Citation Details}

Jaffee, Daniel. 2020. "Enclosing Water: Privatization, Commodification, and Access." 303-323 in Katherine Legun, Julie Keller, Michael Bell, and Michael Carolan (eds.), The Cambridge Handbook of Environmental Sociology (Vol. 2). Cambridge: Cambridge University Press.

This Book Chapter is brought to you for free and open access. It has been accepted for inclusion in Sociology Faculty Publications and Presentations by an authorized administrator of PDXScholar. Please contact us if we can make this document more accessible: pdxscholar@pdx.edu. 


\title{
18 Enclosing Water: Privatization, Commodification, and Access
}

\author{
Daniel Jaffee
}

In the past decade, popular culture and news media have spread the message that the world now faces a crisis of water scarcity, and that fresh water constitutes the "new oil" over which future wars will be fought (Barlow and Clarke 2002). Missing from this formulation, however, is the insight that the "global water crisis" is socially produced, and exacerbated by anthropogenic climate change, ecological degradation, and overextraction by agribusiness and industry (Zwarteveen and Boelens 2014). Nonetheless, the lack of access to potable water for many does indeed constitute a grave emergency. As of 2017, 2.3 billion people had no access to improved sanitation and 844 million people worldwide lacked access to safe drinking water (WHO and UNICEF 2017), although some argue the latter figure is actually closer to 1.8 billion (Goff and Crow 2014). Waterborne diseases including diarrhea and cholera account for approximately 5 percent of all deaths worldwide (UNDP 2006). The increasing inequalities between 'the water 'haves' and 'have nots"" (Zwarteveen and Boelens 2014: 143) have been described as "one of the greatest crimes of the twenty-first century" (Mehta 2016). Lack of access to potable water is a key marker of growing social and environmental inequality on a global scale.

These trends overlap with a major shift in water management regimes over the last three decades, from a "state hydraulic paradigm" in which provision of clean drinking water was understood as a public good and a right of citizenship, to a neoliberal or "market environmentalist" paradigm (Bakker 2005) in which - to cite the influential Dublin Principles of 1992 - water "has economic value in all its competing uses and should be recognized as an economic good" (United Nations 1992). Since the 1990s, a constellation of actors, led by the World Bank and large private water service firms, have pressed the argument that states in the global South had failed to provide access to water to growing and urbanizing populations, and that only the private market could effectively expand water service (Bakker 2013b; Goldman 2007). Only by pricing water at its "true value," the argument continues, can this scarce resource be conserved. To accomplish these goals, private firms should take over the task of providing drinking water from states, making water users into customers, and to do so they would need "full-cost recovery" - guaranteed profit margins backed up by substantial increases in water bills (Castro 2007).

To state the obvious, when a good or resource is commodified or privatized, access is based on the ability to pay. Allowing the market to set a price for water may indeed reduce use, by pushing it out of the reach of those who lack "effective demand" 
(Bond 2008). Yet water is essential for life, and unsubstitutable. This generates a fundamental contradiction that explains the intensity, size, and breadth of opposition to the neoliberalization of water that has emerged in recent decades (Subramaniam and Williford 2012). Struggles over water commodification are often framed in terms of justice - i.e. the injustice of economic or physical barriers to accessing clean drinking water - and this collective resistance is often termed the global water justice movement (Mehta et al. 2014; Zwarteveen and Boelens 2014).

In 2010, the United Nations Assembly and UN Human Rights Council declared water to be a human right, a major victory for water justice advocates (Lederer 2010). However, this formal declaration - while a valuable tool for citizens aiming to hold states accountable - has yet to change substantially the dynamics of access to water. Actually operationalizing the human right to water remains an enormous challenge, one further complicated by market control. Yet private water firms and even some UN officials have argued that the "rights" framing is not incompatible with private provision (Bakker 2010; Sultana and Loftus 2012). Ultimately, debates over the desirability of market versus public (or community) provision of drinking water come down to a basic question: Should affordable access to clean water for all be an inviolable part of the social contract or not?

This chapter examines the global political economy of access to drinking water, with particular attention to the implications for environmental and social justice. (While water for irrigation is also subject to many of the same dynamics of commodification and their negative externalities, it is beyond the scope of this contribution.) The following section reviews some key theoretical approaches to the privatization and commodification of drinking water. The next two sections examine the institutional and ideological drivers, dynamics, and effects of the enclosure of municipal (tap) water supplies, as well as the substantial countermovements it has generated, drawing on case studies from both the global South and the North. After briefly reviewing the present status of municipal water privatization, the chapter then turns to another major modality of water commodification: bottled water. It briefly explores the dramatic growth of this relatively new commodity, its environmental and social externalities, and the grassroots movements opposing water extraction by the global bottled water industry in specific localities. The concluding section discusses the linkages between these various modes of water commodification, and the implications for the future of access to affordable, safe drinking water for all.

\section{Privatization, Commodification, and Accumulation}

The commodification or neoliberalization of nature has generated major social contention, centering both on social justice issues of access to life- and livelihood-sustaining resources and on questions of sustainability and ecological impact. Water exemplifies these tensions. Karl Polanyi (1944) identified what he termed the "fictitious commodities" of land (nature), labor, and money, highlighting their centrality to the destructive tendencies of a "self-regulating" market economy. Neoliberal globalization has since expanded the fictitious commodities 
even further into areas such as (patented) seeds, genes, and life forms (Kloppenburg 2004; Laxer and Soron 2006). Water, as an element of Polanyi's land, offers a compelling contemporary illustration of the dangers of the commodity fiction.

Some scholars have characterized the transformation of water into a marketable commodity as a form of primitive accumulation, drawing on Marx's analysis of the process by which capitalism has separated producers from the social means of subsistence and production (Glassman 2006; Marx 1867; Roberts 2008). Harvey (2003) has usefully extended Marx's framework to emphasize the ongoing nature of these dynamics in the present day, developing the influential concept of "accumulation by dispossession." Harvey argues that accumulation by dispossession is capital's response to an overaccumulation crisis, in which it must expand into new terrains in order to return to or retain profitability (2003: 149). The essence of this process is commodification, the dynamic by which formerly public goods and other non-market functions and services are incorporated into the market. Privatization, Harvey argues, forms the "cutting edge" of accumulation by dispossession, as illustrated by the role of international financial institutions in imposing privatization of public services on debtor nations in the global South. These modern enclosures combine commodification with exclusion, whether that exclusion is economic or physical. Harvey also describes the broad range of social movements against accumulation by dispossession globally, noting a key commonality in their emphasis on "reclaiming the commons" (2003: 166).

Several scholars have applied Harvey's framework explicitly to the commodification of water, examining specific case studies of privatization and the countermovements that they have generated (e.g., Ahlers 2010; Perreault 2013). Spronk and Webber, examining water privatization in Bolivia, observe that accumulation by dispossession involves not only the "privatization of formerly state or public resources but their acquisition by transnational capital in the US and other core economies" (Spronk and Webber 2007: 32). Swyngedouw (2005) argues (echoing Polanyi) that active state intervention is essential to facilitate such accumulation by dispossession. Nonetheless, scholars have documented that the privatization of municipal (tap) water systems poses many obstacles to profitability, a point I return to below.

A dynamic and valuable literature on the political ecology of water has also emerged in recent years, overlapping with many concerns of environmental sociologists. Alex Loftus writes that political ecology "seeks to politicize understandings of the distribution of water," stemming from an understanding that "water and social power are ... mutually constitutive" (Loftus 2009: 953, 959). One of the central concerns of this body of work is to illustrate "the fundamentally socially produced character of ... inequitable hydro-social configurations" (Swyngedouw 2009: 57). Political ecologists examine a range of issues including water infrastructures, urban water, and irrigation, as well as water injustice (Ranganathan and Balazs 2015), the gendered nature of access to and conflicts over water (Ahlers 2005; O'Reilly 2011; Sultana 2011), and municipal water privatization and its countermovements (Bakker 2005; Bakker 2007; Roberts 2008). 


\section{Privatizing Public Water}

In many urban areas of the global South, only upper- and upper-middleincome residents are served by the public tap water networks common in the North, and even where such piped systems are available, supplies may be contaminated or insufficiently treated (Bakker 2010). Middle- and lower-income urban and periurban residents typically rely on a mix of less formal sources, including refilling stations and water vendors selling trucked or locally bottled water, which costs far more than their wealthier neighbors pay for tap water (Godoy 2010; Malkin 2012). Others turn to communal standpipes, household wells, or even untreated surface water (Liddle, Mager and Nel 2014; Narain 2014). In part due to this growing crisis of quantity and quality, drinking water is increasingly seen as a profitable commodity to be sold at market rates. This has facilitated the emergence of a nearly $\$ 500$ billion global water services industry, one-fourth of which is presently controlled by two French-based multinational corporations, Veolia and Suez (Arup 2015).

While the wholesale sell-off of public water utilities in the United Kingdom under Margaret Thatcher in 1989 is often cited as the functional start of the global push to privatize water (Bakker 2005), this dynamic actually dates back to Chicago Schoolinfluenced policies implemented by the Pinochet dictatorship in Chile beginning in 1980 (Harris 2013). The privatization of tap water systems in the global South was largely imposed through lending conditionality by international financial institutions, primarily the World Bank and IMF, under so-called structural adjustment programs. Starting in the late 1980s and 1990s, these agencies mandated that debtor governments offer up public utilities for concession or sale as a condition of debt renegotiation, arguing that states had failed to provide "water for all" and that the private sector was uniquely qualified to fill this role (Conca 2008; Goldman 2007). It is true that in the neoliberal era, many Southern states have indeed been hard-pressed to extend piped water networks to keep pace with rapid urbanization, yet that is often due to the very same strictures of debt servicing (Bakker 2013b). Nonetheless, water is also essential for life, and privatization has in some cases made it "so unaffordable that citizens are forced to drink water from contaminated sources" (Kurland and Zell 2011: 329). Therefore, the struggle over public versus market provision of water carries profound implications for human rights, health, and social justice. When access to clean water is based solely on the ability to pay, some people will lose access, which can be deadly.

In reality, the term "privatization" subsumes a wide variety of forms of market involvement, ranging from (relatively uncommon) outright asset sales like those in the UK, to long-term leases or concession contracts - "outsourcing" arrangements in which water systems remain publicly owned but private firms are responsible for operations, maintenance, and sometimes infrastructure investments - to "corporatized" public water utilities that now operate on strict market principles (Bakker 2014; Castro 2007; McDonald 2016). The large majority of the "privatizations" that have caused major social protest in the global South were in fact multi-decade concessions - often termed "public-private partnerships" (PPPs) by proponents - which typically guarantee the corporate operator a minimum profit 
margin and the freedom to set water rates (Bakker 2014). All of these constitute forms of enclosure, because access to water is mediated by the market. Yet scholars disagree on the extent to which privatization, commodification, and marketization overlap. Bakker, for example, argues that due in part to water's biophysical and sociocultural qualities, "private ownership and the introduction of markets do not necessarily entail commodification," leading her to characterize water as an "uncooperative commodity" that poses barriers to its full conversion into a market good (Bakker 2005: 559). However, scholarly debates over the boundaries between commodification and privatization are usually of less concern to local communities and grassroots water justice activists, many of whom employ "privatization" as a broad term encompassing all forms of market control over water, which they view as antithetical to human rights and the public interest (Campero Arena 2016). In this chapter, I use the term "privatization" to refer to multiple arrangements that cede control over key functions of public (or community) water management to private firms, ranging from PPPs (concessions and leases) to outright system sales.

The World Bank, private water firms, and other key players have since the early 1990s manufactured a global "consensus" around the private provision of water, creating "transnational policy networks" that incorporated Southern bureaucrats, global water firms, NGOs, and putative "civil society" entities such as the World Water Council (Goldman 2007). Goldman (2005) argues that water privatization is emblematic of the World Bank's newest policy regime, which he terms "green neoliberalism" - an approach fusing global discourses of sustainable development with the extension of market fundamentalism. Bakker (2014: 474-475) describes this paradigm as market environmentalism, a "doctrine premised on the synergies between environmental conservation and protection, economic growth, market economies, and neoliberal governance." By whatever name, this regime led to a dramatic increase in concessions and facilitated the growth of a global "cartel" of private water service firms, two of which - French-based Suez and Veolia - at their peak controlled over 70 percent of the private water sector worldwide (Barlow 2007).

A substantial body of literature examines the results of privatization in the global South - particularly the dominant model of long-term concession contracts with large transnational firms. While this literature partly reflects the ideological divide over privatization, and some research has found increases in water connections under private concessions in certain cities, the large majority of studies concur that market involvement has failed to substantially expand water service, let alone meet the stated goal of providing "water for all" (Castro 2008; Swyngedouw 2005). The World Bank itself has acknowledged that concession contracts did not generate significant numbers of new water connections (World Bank 2005). The track record of municipal water privatization across the South includes large rate hikes, deviations from promised levels of service, increased instances of unsafe water, the spread of diseases including cholera, pollution and sewage spills, and increased water shutoffs for nonpayment that have forced users to turn to contaminated water sources (Food and Water Watch 2011). 
Some of the touted financial efficiencies gained from these arrangements resulted from substantial layoffs of public utility employees under private management, such as in the 1993 concession of the Buenos Aires water system to a consortium led by Suez (Casarin, Delfino, and Delfino 2007). When privatization is imposed by creditors under a tight time frame, the resulting "fire sales" (often with very few bidders) can generate far less revenue for debtor states than projected, highlighting the dynamics of accumulation by dispossession at work (Rankin and Smith 2015; Vilas 2004).

Privatization also has major gendered effects. Ahlers writes that "unequal gendered access to resources is perpetuated and legitimized by the introduction of market mechanisms in the water sector" (Ahlers 2005: 57). Increased water tariffs in pursuit of "full-cost recovery" can reconfigure gendered household economies and divisions of labor, particularly if families lose access to potable water supply due to disconnection (O’Reilly 2011).

\section{Contesting and Reversing Privatization}

Public opposition to the neoliberalization of water has accompanied privatization around the globe. Substantial protests have erupted not only in the wellstudied Bolivian "water wars" in Cochabamba and El Alto (e.g., Spronk 2015), but also in Ecuador, Uruguay, Argentina, Nicaragua, El Salvador, Tanzania, South Africa, Nigeria, and many other countries (Castro 2008; Romano 2012, Terhorst, Olivera and Dwinell 2013). Many of the citizens and grassroots activists in these uprisings have received support from a broad network of civil society groups and NGOs that collectively constitute the global water justice movement (Barlow 2014; Lobina, Terhorst, and Popov 2011; Nelson 2017). This constellation of actors can be conceptualized as a Polanyian countermovement advocating decommodification of the water commons.

Water justice activists and other opponents of privatization argue that public utilities like water systems - typically understood as natural monopolies - are inherently unsuited to market control, since the profit motive is incompatible with the need for long-term investments in water quality and system maintenance (Barlow 2007; Snitow, Kaufman and Fox 2007). Because the rate hikes needed to ensure profit margins cause the exclusion of those unable to pay, they insist that subjecting a life-sustaining resource to market discipline is inimical to public well-being, and that it must be managed on a non-profit basis (Barlow, 2007).

This critique extends to the environmental implications of market control as well. Zwarteveen and Boelens write that "water justice includes but transcends questions of distribution ... and is intimately linked to the integrity of ecosystems" (Zwarteveen and Boelens 2014: 143). Mehta and her coauthors similarly observe that "struggles to access water are also struggles about environmental justice and sustainability" (Mehta et al. 2014: 158).

Beginning in the early 2000s, many water concession contracts were terminated by municipal or national governments, due to firms' noncompliance with contract terms, failure to invest in infrastructure or system extension, public opposition, or 
changing state political ideologies (especially in Latin America). Other contracts were ended by the private firms themselves due to public protest and lack of profitability (Food and Water Watch 2011; Hall, Lobina, and Corral 2011; Vidal 2006). The German firm RWE, formerly the third largest private water corporation, has sold off much of its $\$ 10$ billion worth of water holdings worldwide, including the major subsidiary Thames Water (Esterl 2006). Overall, municipal water privatization has proved to be insufficiently profitable in predominantly poor urban areas in the South (Swyngedouw 2005). Loftus writes that "it is incredibly difficult to make the profits expected by private investors from the large, long-term needs of infrastructural development for poor people" (Loftus 2009: 957).

Public opposition and the poor overall track record of privatizations (including poor water quality, soaring rates, and major labor conflict) has led hundreds of cities to "remunicipalize" their water systems in the past ten to fifteen years, ending private contracts and returning to public management. As of 2017 there were 267 documented cases of water remunicipalization worldwide (Kishimoto and Petitjean 2017). Also stemming from these water justice struggles, several "pink tide" Latin American states have incorporated explicit bans on water privatization into their constitutions, including Uruguay, Bolivia, and Ecuador (Hall, Lobina and De la Motte 2009; Harris 2013). On the other hand, the right-wing Brazilian government has recently embarked on a privatization push. Some remunicipalized water utilities in the South continue to struggle with low investment, indebtedness, and a limited ability to expand water networks (Driessen 2008; Spronk 2015). One model advocated by water justice groups to address such challenges is "public-public partnerships," in which water utilities partner with utilities, NGOs, or labor unions in other cities and nations to share expertise, pool resources, and increase efficiencies (Food and Water Watch 2012b).

South Africa represents a dramatic case of the harmful social consequences of the neoliberalization and marketization of water, even in the absence of outright privatization. Despite inclusion of the right to water in its post-Apartheid constitution and the adoption of a "free basic water" policy guaranteeing access to a minimal amount (25 liters per person daily) without charge, the ANC government has implemented pre-paid water metering on a broad scale, leading to shutoffs of up to 10 million people for nonpayment. These policies have forced many to turn to unsafe water sources, leading to outbreaks of cholera and generating substantial protest movements against metering and shutoffs (Goldman 2007; Ruiters 2007; Smith and Hanson 2003). In a landmark 2009 decision in a lawsuit brought by poor residents of Phiri, Soweto against the recently deprivatized Johannesburg Water, the Constitutional Court upheld the metering policy and ruled that the meager basic water allocation was sufficient (Dugard 2010). Many observers argue this decision constitutes a clear denial of the human right to water (e.g., Bond 2012).

\section{Austerity, Affordability, and Contamination in the North}

Market involvement in tap water in the global North exhibits some of the same dynamics as in the South. The first drinking water systems were largely 
developed by private firms in the eighteenth and nineteenth centuries, but in North America and much of Europe, city governments had largely taken over operating water systems by the early twentieth century, due to major problems with disease, poor water quality, pollution, inadequate pressure and supply, and other factors. However, since the 1990 s, pressure to return to market provision has resurfaced, generating vocal countermovements (Food and Water Watch 2012a; Varghese 2007). Several large US cities entered into private concession contracts with Suez, Veolia, and other firms to manage drinking water and sewerage systems, including Atlanta, Indianapolis, New Orleans, Indianapolis, and Stockton, CA. Due partly to their poor track record (large rate hikes, more frequent water quality emergencies, and diminished service levels), virtually all of the high-profile concessions in major cities have since been reversed, adding to the global remunicipalization trend (Esterl 2006; Robinson 2013; Snitow, Kaufman and Fox 2007).

Nevertheless, management of public water systems in the United States is increasingly hampered by deteriorating public water and sewer infrastructure resulting from decades of underinvestment and fiscal austerity, leading to an infrastructure maintenance backlog estimated at \$1 trillion (American Water Works Association 2012). The dramatically declining US federal investment in state and local water infrastructure since the early 1980 s is emblematic of the retreat of states from service provision under neoliberal restructuring, which has especially come to the fore since the Great Recession (Peck 2015; Szasz 2007). The rising burden of infrastructure maintenance, combined with local fiscal crises causing budget cuts to water utilities, has made "public-private partnerships" appealing to many cash-strapped cities, such as Baltimore, where Suez has worked to persuade public officials to approve a concession of the city's water system (Sloan 2016). Private equity firms such as the Carlyle Group have increasingly attempted to buy out both private and public water utilities in the United States in a search for high short-term returns (Food and Water Watch 2012a). A few US states, including New Jersey, have passed legislation incentivizing private sector involvement in upgrades of public water systems (Augenstein 2015). Some observers have analyzed these phenomena as instances of "disaster capitalism" (Klein 2007), emphasizing how political elites and investors can seize upon crises, whether natural disasters or fiscal shocks, to advance the privatization or commodification of public resources.

Despite these trends, the proportion of the US population served by public drinking water systems has actually risen slightly, from 83 percent in 2007 to 87 percent in 2015 (Food and Water Watch 2016). Studies have documented that customers of privately owned utilities pay on average 59 percent more than those of public utilities (Food and Water Watch 2016), due to both higher borrowing costs and the imperative to generate returns for investors (Food and Water Watch 2017b; Wait and Petrie 2017).

However, although tap water provided by the public sector is less expensive, the United States is now experiencing a burgeoning crisis of water affordability. Municipalities forced to take over the burden of water and sewer system maintenance from the federal government have passed the costs on to users through rising bills. A 2017 study found that nearly 12 percent of US households have unaffordable 
water and wastewater bills (defined as more than 4.5 percent of household income) a figure projected to rise to a startling 35 percent by 2022 if current trends continue (Mack and Wrase 2017).

While the affordability crisis is nationwide, its epicenter is arguably Detroit, where mass shutoffs of up to 100,000 poor households for nonpayment of water bills since 2014 have drawn international media coverage, condemnation from the UN Special Rapporteur on the Right to Water, and dramatic protests by residents (Kornberg 2016; Rushe 2014). Some critics allege this practice is aimed at reducing debt to prepare the water utility for privatization (Rector 2016). Baltimore and Pittsburgh also have experienced soaring water bills and large-scale water shutoffs (Food and Water Watch 2017b). These policies raise obvious and troubling parallels to the struggles over unaffordability, shutoffs, and violations of the human right to water in South Africa and elsewhere in the South.

Concerns about unsafe drinking water in the United States have also risen sharply in recent years, drawing national attention to the unequal racial and class distribution of the risks associated with decaying water infrastructure (Miller and Wesley 2016). The case of Flint, Michigan represents a particularly dramatic and troubling illustration of these dynamics. Flint was one of several Michigan cities that the Republican governor placed under the control of appointed emergency fiscal managers (EFMs), a practice critics charge eviscerates local sovereignty and constitutes a form of disaster capitalism, by bypassing elected local officials and promoting the sale of public assets (Rector 2016). Flint's EFM in 2014 mandated that the city switch its water supply from the Detroit water system to the Flint River, which was both highly polluted and corrosive. The EFM, in a move to save $\$ 5$ million, made the fateful decision not to add anti-corrosion chemicals to the water, resulting in widespread contamination from corroding pipes and causing Flint residents to drink highly toxic drinking water for over a year, with lead levels in tap water as high as 10,000 times over the EPA legal limit (Blow 2016; Butler, Scammell, and Benson 2016). This has caused severe lead poisoning, especially of Flint's children, which can lead to irreversible organ and developmental damage (Bellinger 2016). Costs to repair the system are now estimated in the billions of dollars.

Scholars have also linked water privatization more broadly to environmental injustice. Greiner (2016) finds that water utility privatization in the United States is correlated with higher populations of racial minorities, arguing that "communities that have traditionally been politically marginalized are at greater risk of being subjected to neoliberal processes," and that water system privatization should be considered "an instance of environmental inequality" (16-17). The strong racial and class element in the Flint case - the city is 63 percent African-American and disproportionately low-income - has led many critics to charge that this represents an extreme case of environmental injustice (Pulido 2016; Ranganathan 2016). Recent studies also show that far from being limited to a few cases such as Flint, lead contamination has become a widespread problem in US water systems, affecting at least 18 million people (Milman 2016).

In Europe, many municipal tap water systems had also long been in public hands, with exceptions including France, home to Veolia and Suez. Beginning in the 1980s, 
the UK became the site of the most dramatic experiment in water privatization, and cities in Spain and other nations also began to privatize water systems. Since the financial crisis, however, the strategy of water privatization as part of enforced austerity conditionality for debtor states - long an element of structural adjustment policies in the global South - has now been extended throughout the Eurozone periphery, with privatization mandates imposed by the "troika" of the IMF, European Union, and European Central Bank on Portugal (Bieler and Jordan 2017), Ireland (Mercille and Murphy 2015), Spain (Gonzalez-Gomez, Garcia-Rubio, and Gonzalez-Martinez 2014), and Greece (Pempetzoglou and Patergiannaki 2017). Implementation of "full-cost recovery" policies has led to substantial water shutoffs here too, and privatization has generated major countermovements (Zurita et al. 2015), particularly in Greece and in Italy, where a 2011 national referendum banned water privatization (Carrozza and Fantini 2016). In the 2019 UK General Election, the Labour Party promised to renationalize water and other privatized services if elected, a move polling shows is supported by a sizeable majority of the British public (The Guardian 2017).

\section{Countercurrents: The Present Status of Water Privatization}

The overall panorama as of this writing is mixed, with substantial geographic variation. As of 2015, private firms supplied tap water and/or sewerage services to 1.05 billion people, or 16 percent of the global population - up from 50 million people in 1990 (Arup 2015). At the same time, there has been a substantial retreat by the large multinational water firms in Latin America (with exceptions including Mexico and Colombia), in some large Southern cities including Jakarta, Indonesia and Accra, Ghana, and in western Europe. Pierce argues that this "strategic retreat" in the early- and mid-2000s has been followed by a "shallow expansion" of privatization since the Great Recession, with the multinational firms playing a reduced role, and much greater involvement by national capital, as well as private equity investors (Pierce 2015). This expansion of private water provision is bimodal: one the one hand, there is substantial growth in middle-income nations, notably China, India, and (as of 2017) Brazil, while on the other hand, it is being imposed from above through austerity in the Eurozone periphery (Pierce 2015). The enforced privatization of water in southern Europe offers a stark parallel to the earlier wave of market expansion through structural adjustment in Southern debtor states, pointing to strong continuities in the dynamics (and the agents) of accumulation by dispossession. In fact, structural adjustment in the global South has been renamed but not rescinded: nations participating in the World Bank's Highly Indebted Poor Countries (HIPC) initiative still must implement utility privatization as a precondition for securing debt relief. Indeed, Bakker (2013a: 257) terms the current state of affairs a "refinement, rather than a retrenchment, of the neoliberal project" in water.

To sum up, there are substantial countercurrents at work here. A genuine remunicipalization and deprivatization trend in some regions coexists with a countertendency toward new privatizations, most pronounced in semiperipheral 
nations and now in the core under neoliberal austerity, whether imposed by creditors or transmitted through fiscal crises of the state. The number of people served by privatized municipal drinking water has increased, but more gradually than many boosters or critics had expected. However, another major modality of water commodification is advancing far more rapidly: bottled water.

\section{Bottled Water}

In a few short decades, bottled water has been transformed from a niche product into a ubiquitous consumer commodity. In the United States, bottled water consumption grew from two gallons per capita per year in 1978 to over 39 gallons in 2016 (Gleick 2010; Rodwan 2017), putting it in fourth place behind Mexico, Thailand, and Italy, and surpassing soda as the nation's most-consumed beverage (Beverage Marketing Corporation 2017). China's annual bottled water consumption has doubled to over 22 billion gallons since 2011, representing one-quarter of the global total (Rodwan 2017). The international bottled water market, dominated by four transnational agrifood corporations (Nestlé, Coca-Cola, Pepsico, and Danone), was estimated at $\$ 198$ billion in 2017 and is expected to reach $\$ 307$ billion by 2024 (Transparency Market Research 2018). This fairly young commodity is situated at the intersection of several major sociopolitical trends, including the shift toward individualized protection from environmental risk (Szasz 2007), the effects of neoliberal austerity on public infrastructure, and falling trust in tap water.

The dynamics driving bottled water's growth differ by world region. In parts of the South, many states have been unable to extend tap water systems sufficiently as urbanization outpaces the existing infrastructure. In this context, corporations, consumers, and governments have increasingly turned to bottled water - both in singleserving containers and large multi-gallon jugs - as the solution to actual or perceived drinking water scarcity (Hawkins 2017). In many cities, there is a two-tier market: the transnational bottled water firms are buying local companies and targeting middle- and upper-income consumers with branded water, while the remaining local vendors supply working-class residents with water of often uncertain origin and quality (Girard 2009). Yet even the cheapest options are prohibitive for the poorest residents (Greene 2014), illustrating the troubling implications of this commodity for the human right to water.

In the North, the reasons for bottled water's rise are different. Bottled water firms promote their product by appealing to consumer concerns with purity, social status, and health. Industry advertising campaigns have also focused on disparaging tap water, both capitalizing on and contributing to public fears about water quality (Gleick 2010; Parag and Roberts 2009). News coverage of instances of toxic tap water, such as in Flint or in Walkerton, Ontario, further increases the demand for bottled water, despite the reality that bottled water in the United States and Canada is far less regulated than tap water (Gleick 2010). Ironically, those bottles increasingly contain purified tap water, rather than groundwater or spring water: the proportion of US bottled water drawn from already-treated municipal sources rose from 49 percent 
in 2008 to 63 percent in 2017 (Food and Water Watch 2017a). Among US adults, bottled water now accounts for a remarkable 44 percent of total drinking water consumption (Drewnowski, Rehm, and Constant 2013), even though it typically costs thousands of times more per unit volume than tap water, and is far less regulated (NRDC 1999).

Bottled water also generates substantial negative environmental externalities, including energy footprints up to 2,000 times higher than tap water (Gleick and Cooley 2009), major water waste in manufacturing, and the enormous terrestrial and marine waste problems generated worldwide by the disposal of approximately 500 billion bottles annually, an issue some observers have termed an ecological threat on par with climate change (Laville and Taylor 2017).

A range of movements has emerged in opposition to bottled water, which can be divided into two broad categories: those opposing water extraction by the industry, and those challenging bottled water consumption. On the consumption end, movements to "take back the tap," primarily in the North, have successfully lobbied a number of city governments, universities, and other institutions to ban purchases of bottled water, reinvest in public water infrastructure (including water fountains), and launch campaigns to promote the high quality of their tap water (Gentile 2008; Lagos 2014).

Movements against the bottling industry's groundwater extraction have developed in both South and North. While the volumes extracted are often insignificant relative to total groundwater usage, they can have damaging hydrological and ecological effects in specific localities, including depletion, drawdown, or contamination of aquifers (Gleick 2010; Barlow 2014). In North America, the majority of this facet of activism has been focused on Nestlé, the industry leader, which has found it increasingly challenging to establish new spring water and groundwater extraction sites. A decade-long attempt to establish a bottling plant in Oregon's Columbia Gorge (Jaffee and Newman 2013a) was defeated in 2017 by a coalition of grassroots groups and environmental NGOs, and in Ontario, Canada, the company has faced sustained public opposition to new and existing wells as well as increased extraction fees and regulatory scrutiny from the provincial government (Jaffee and Case 2018). Conflicts over water extraction by the bottled water and beverage industry have also emerged in the global South, notably in India, Pakistan, and Brazil (Rosemann 2005; Drew 2008; Sitisarn 2012).

Bakker has influentially framed water as an "uncooperative commodity," whose biophysical qualities - it is heavy and difficult to transport - render it a poor fit with the demands of capital accumulation (2005). In contrast, bottled water's plastic package and extreme portability, along with the political-economic shifts that have enabled its rapid growth, have allowed it to avoid many of these constraints (Jaffee and Newman 2013a). While municipal tap water systems constitute natural monopolies with substantial sunk infrastructure costs, are inherently tied to place, and have low price elasticity, bottled water is both more profitable and far more mobile, making it a "more perfect commodity" for capital accumulation (Jaffee and Newman 2013b). However, while bottled water represents an unambiguous case of commodification and a clear instance of accumulation by dispossession, it typically does not 
constitute outright privatization, emphasizing that the latter is far from the only way the market can assert control over water.

In closing this section, it is worth stepping back to acknowledge the social-justice and ecological costs of bottled water's dramatic growth. Considering its vastly higher carbon and water footprints and the enormous waste problems caused by disposal of half a trillion single-use plastic bottles annually, despite the ready availability of a far cheaper and less damaging alternative (tap water), it would be hard to identify another commodity that encapsulates the concept of unsustainability so dramatically. Given the prominent role it has played in filling water needs in the wake of austerity-induced crises of toxic water in Flint and elsewhere, bottled water can also be viewed as an important marker of water injustice. While it may have a legitimate short-term role to play in genuine disasters, Gleick et al. (2002: 12) argue that sales of bottled water "must not be considered acceptable substitutes for adequate municipal water supply. Bottled water rarely provides adequate volumes of water for domestic use, and the costs of such water are typically exorbitant."

\section{Conclusion}

In February 2018, municipal authorities in Cape Town, South Africa made the stunning announcement that by mid-summer, the city would reach "Day Zero" the moment its municipal water supply would effectively run dry and water service would be cut off to over one million homes (Frederick 2018). After three years of extreme drought, the city's reservoir was virtually depleted. Government officials implemented severe water rationing - with residents allowed to fill containers at collective taps with 25 liters per day per person - but also acknowledged they were preparing for "anarchy" if the taps ran dry. In this quasi-apocalyptic context, the wealthy dug personal wells and built water storage tanks, while most residents stocked up on bottled water to fill the void, with sales (and imports) booming (Watts 2018). While rains in mid-2018 postponed "Day Zero" for the moment, other large cities, including Delhi, are now approaching similar crises. (Oaten and Patidar, 2020).

The fates of these two modes of water provision - tap and bottled - are closely linked. The growing embrace of bottled water as an acceptable, or even a preferred, mode of delivery has troubling implications not only for the century-old project of universal public provision of safe drinking water in much of the North, but also for ensuring access to drinking water worldwide. To the extent that the increasing prevalence of bottled water enables further disinvestment in public drinking water infrastructure, this commodity arguably poses a greater threat to drinking water access than privatization of municipal tap water itself (Jaffee and Newman 2013a). According to Barlow (2007: 100-101), bottled water "allows people to view water as a commodity and sets the stage - one bottle at a time - for the complete corporate takeover of water."

Water's unique status as unsubstitutable and essential for life helps to explain the intensity and vitality of movements for water justice worldwide. These 
countermovements have proven partially successful at reversing, slowing, or preventing privatization, and in posing obstacles to the further commodification of water. As such, they can be understood as movements for decommodification (Vail 2010), which is closely tied to the affirmation of water as a human right.

Finally, we must return to the question posed at the outset: Do we agree that affordable access to clean drinking water for all is an essential part of the social contract, or do we not? If the answer is yes, it appears highly unlikely that this right will be achieved or ensured through market provision. Although capital has asserted substantial if highly uneven control over water worldwide, hope for restoring and expanding equitable access to clean, safe drinking water for all ultimately rests in the hands of states, citizens, communities, and social movements.

\section{References}

Ahlers, Rhodante. 2005. "Gender Dimensions of Neoliberal Water Policy in Mexico and Bolivia: Empowering or Disempowering?" pp. 53-71 in Opposing Currents: The Politics of Water and Gender in Latin America, edited by V. Bennett, S. DavilaPoblete, and M. Nieves Rico. Pittsburgh, PA: University of Pittsburgh Press.

Ahlers, Rhodante. 2010. "Fixing and Nixing: The Politics of Water Privatization." Review of Radical Political Economics 42(2):213-230.

American Water Works Association. 2012. Buried No Longer: Confronting America's Water Infrastructure Challenge. Denver, CO: American Water Works Association.

Arup. 2015. In-Depth Water Yearbook 2014-2015. London: Arup.

Augenstein, Seth. 2015. "Christie Signs Law Greenlighting Fast Track Sale of N.J. Public Water Systems.” NJ.com (February 5). Retrieved February 15, 2018 (www.nj.com /politics/index.ssf/2015/02/christie_signs_law_greenlighting_sales_of_public_wa ter_systems.html).

Bakker, Karen. 2005. "Neoliberalizing Nature? Market Environmentalism in Water Supply in England and Wales." Annals of the Association of American Geographers 95 (3):542-565.

Bakker, Karen. 2007. "The 'Commons' Versus the 'Commodity': Alter-Globalization, AntiPrivatization and the Human Right to Water in the Global South." Antipode 39 (3):430-455.

Bakker, Karen. 2010. Privatizing Water: Governance Failure and the World's Urban Water Crisis. Ithaca, NY: Cornell University Press.

Bakker, Karen. 2013a. "Neoliberal Versus Postneoliberal Water: Geographies of Privatization and Resistance." Annals of the Association of American Geographers 103 (2):253-260.

Bakker, Karen. 2013b. "Constructing 'Public' Water: The World Bank, Urban Water Supply, and the Biopolitics of Development." Environment and Planning D-Society \& Space 31(2):280-300.

Bakker, Karen. 2014. "The Business of Water: Market Environmentalism in the Water Sector." Annual Review of Environment \& Resources 39(1):469-494.

Barlow, Maude. 2007. Blue Covenant: The Global Water Crisis and the Coming Battle for the Right to Water. New York: The New Press. 
Barlow, Maude. 2014. Blue Future: Protecting Water for People and the Planet Forever. New York: The New Press.

Barlow, Maude and Tony Clarke. 2002. Blue Gold: The Fight to Stop the Corporate Theft of the World's Water. New York: The New Press.

Bellinger, David C. 2016. "Lead Contamination in Flint - an Abject Failure to Protect Public Health." New England Journal of Medicine 374 (March 24):1101-1103.

Beverage Marketing Corporation. 2017, "Bottled Water Becomes Number-One Beverage in the US, Data from Beverage Marketing Corporation Show." Retrieved March 10, 2018 (www.beveragemarketing.com/news-detail.asp?id=438).

Bieler, Andreas, and Jamie Jordan. 2017. "Commodification and 'the Commons': The Politics of Privatising Public Water in Greece and Portugal During the Eurozone Crisis." European Journal of International Relations 24(4):934-957. Doi:1354066117728383.

Blow, Charles M. 2016. “The Poisoning of Flint's Water.” New York Times (January 21), www .nytimes.com/2016/01/21/opinion/the-poisoning-of-flints-water.html.

Bond, Patrick. 2008. "Macrodynamics of Globalisation, Uneven Urban Development and the Commodification of Water." Law, Social Justice and Global Development (An Electronic Law Journal) 11:1-14.

Bond, Patrick. 2012. "The Right to the City and the Eco-Social Commoning of Water: Discursive and Political Lessons from South Africa." pp. 190-205 in The Right to Water, edited by F. Sultana and A. Loftus. London: Earthscan.

Butler, Lindsey J., Madeleine K. Scammell and Eugene B. Benson. 2016. "The Flint, Michigan, Water Crisis: A Case Study in Regulatory Failure and Environmental Injustice." Environmental Justice 9(4):93-97.

Campero Arena, Claudia. 2016. Water Campaigner, Blue Planet Project (Personal Communication). Mexico City, January 30.

Carrozza, Chiara and Emanuele Fantini. 2016. "The Italian Water Movement and the Politics of the Commons." Water Alternatives-an Interdisciplinary Journal on Water Politics and Development 9(1):99-119.

Casarin, Ariel A., Jose A. Delfino and Maria Eugenia Delfino. 2007. "Failures in Water Reform: Lessons from the Buenos Aires's Concession." Utilities Policy 15 (4):234-247.

Castro, José Esteban. 2007. "Poverty and Citizenship: Sociological Perspectives on Water Services and Public-Private Participation." Geoforum 38:756-771.

Castro, José Esteban. 2008. "Water Struggles, Citizenship and Governance in Latin America." Development 51:72-76.

Conca, Ken. 2008. "The United States and International Water Policy." Journal of Environment \& Development 17(3):215-237.

Drew, Georgina. 2008. "From the Groundwater Up: Asserting Water Rights in India." Development 51(1): 37-41.

Drewnowski, Adam, Colin D. Rehm, and Florence Constant. 2013. "Water and Beverage Consumption Among Adults in the United States: Cross-Sectional Study Using Data from NHANES 2005-2010.” BMC Public Health 13(1):1-19 doi:10.1186/ 1471-2458-13-1068.

Driessen, Travis. 2008. "Collective Management Strategies and Elite Resistance in Cochabamba, Bolivia." Development 51(1):89-95.

Dugard, Jackie. 2010. "Can Human Rights Transcend the Commercialization of Water in South Africa? Soweto's Legal Fight for an Equitable Water Policy." Review of Radical Political Economics 42(2):175-194. 
Esterl, Mike. 2006. "Dry Hole: Great Expectations for Private Water Fail to Pan Out." Wall Street Journal (June 26), www.wsj.com/articles/SB115128641717890452.

Food and Water Watch. 2011. Water = Life: How Privatization Undermines the Human Right to Water. Washington, DC: Food and Water Watch.

Food and Water Watch. 2012a. Private Equity Public Inequity: The Public Cost of Private Equity Takeovers of U.S. Water Infrastructure. Washington, DC: Food and Water Watch.

Food and Water Watch. 2012b. Public-Public Partnerships: An Alternative Model to Leverage the Capacity of Municipal Water Utilities. Washington, DC: Food and Water Watch.

Food and Water Watch. 2016. The State of Public Water in the United States. Washington, DC: Food and Water Watch.

Food and Water Watch. 2017a. Take Back the Tap: The Big Business Hustle of Bottled Water. Washington, DC: Food and Water Watch.

Food and Water Watch. 2017b. Water Injustice: Economic and Racial Disparities in Access to Safe and Clean Water in the United States. Washington, DC: Food and Water Watch.

Frederick, Franklin. 2018. "Water: The Warning Coming from South Africa." Dawn News (February 15). Retrieved February 28, 2018 (www.thedawn-news.org/2018/02/27/ water-the-warning-coming-from-south-africa/).

Gentile, Annie. 2008. "Mayors Push Benefits of Cities' Tap Water." American City \& County 123(9):18-20.

Girard, Richard. 2009. "Bottled Water Industry Targets a New Market: The Global South." AlterNet, June 15. Accessed September 1, 2011. www.alternet.org/module/printver sion/140671.

Glassman, Jim. 2006. "Primitive Accumulation, Accumulation by Dispossession, Accumulation by 'Extra-Economic' Means.” Progress in Human Geography 30(5):608-625.

Gleick, Peter H., Gary Wolff, Elizabeth L. Chalecki, and Rachel Reyes. 2002. The New Economy of Water: The Risks and Benefits of Globalization and Privatization of Fresh Water. Oakland, CA: Pacific Institute.

Gleick, Peter H. 2010. Bottled and Sold: The Story Behind Our Obsession with Bottled Water. Washington, DC: Island Press.

Gleick, Peter H., and Heather S. Cooley. 2009. "Energy Implications of Bottled Water." Environmental Research Letters 4(1):1-6. doi:10.1088/1748-9326/4/1/014009.

Godoy, Emilio. 2010. "Mexico: Soaring Bottled Water Use Highlights Mistrust of Tap Water." Inter Press Service, www.globalissues.org/news/2010/09/23/7056.

Goff, Matthew and Ben Crow. 2014. "What Is Water Equity? The Unfortunate Consequences of a Global Focus on 'Drinking Water'." Water International 39(2):159-171.

Goldman, Michael. 2005. Imperial Nature: The World Bank and Struggles for Social Justice in the Age of Globalization. New Haven CT: Yale University Press.

Goldman, Michael. 2007. "How 'Water for All!' Policy Became Hegemonic: The Power of the World Bank and Its Transnational Policy Networks." Geoforum 38:786-800.

Gonzalez-Gomez, Francisco, Miguel A. Garcia-Rubio, and Jesús Gonzalez-Martinez. 2014. "Beyond the Public-Private Controversy in Urban Water Management in Spain." Utilities Policy 31:1-9.

Greene, Joshua Cullen. 2014. "The Bottled Water Industry in Mexico." Master of Global Policy Studies Master's thesis, University of Texas at Austin.

Greiner, Patrick. 2016. "Social Drivers of Water Utility Privatization in the United States: An Examination of the Presence of Variegated Neoliberal Strategies in the Water Utility Sector." Rural Sociology 81(3):387-406. 
Hall, David, Emanuele Lobina and Robin De la Motte. 2009. Making Water Privatisation Illegal: New Laws in Netherlands and Uruguay. London: Public Service International Research Unit.

Hall, David, Emanele Lobina and Violeta Corral. 2011. Trends in Water Privatization. London: Public Services International Research Unit.

Harris, Leila M. 2013. "Variable Histories and Geographies of Marketization and Privatization." pp. 118-32 in Contemporary Water Governance in the Global South: Scarcity, Marketization and Participation, edited by L. M. Harris, J. A. Goldin, and C. Sneddon. London: Routledge.

Harvey, David. 2003. The New Imperialism. New York: Oxford University Press.

Hawkins, Gay. 2017. "The Impacts of Bottled Water: An Analysis of Bottled Water Markets and their Interactions with Tap Water Provision." WIREs Water 4 (3). doi:10.1002/ wat2.1203.

Jaffee, Daniel, and Soren Newman. 2013a. "A Bottle Half Empty: Bottled Water, Commodification, and Contestation." Organization \& Environment 26(3):318-335.

Jaffee, Daniel, and Soren Newman. 2013b. "A More Perfect Commodity: Bottled Water, Global Accumulation, and Local Contestation." Rural Sociology 78(1):1-28.

Jaffee, Daniel, and Robert A. Case. 2018. "Draining Us Dry: Scarcity Discourses in Contention over Bottled Water Extraction." Local Environment 23(4):485-501.

Kishimoto, Satoko, and Olivier Petitjean. 2017. Reclaiming Public Services: How Cities and Citizens Are Turning Back Privatisation. Amsterdam: Transnational Institute.

Klein, Naomi. 2007. The Shock Doctrine: The Rise of Disaster Capitalism. Toronto: Knopf Canada.

Kloppenburg, Jack R. 2004. First the Seed: The Political Economy of Plant Biotechnology, 1492-2000 (2nd Ed.). Madison, WI: University of Wisconsin Press.

Kornberg, Dana. 2016. "The Structural Origins of Territorial Stigma: Water and Racial Politics in Metropolitan Detroit, 1950s-2010s." International Journal of Urban and Regional Research 40(2):263-283.

Kurland, Nancy B. and Deone Zell. 2011. "Water and Business: A Taxonomy and Review of the Research." Organization \& Environment 23(3):316-353.

Lagos, Marisa. 2014. "S.F. Supervisors Back Ban on Sale of Plastic Water Bottles." San Francisco Chronicle (March 5), www.sfgate.com/bayarea/article/S-F-supervisorsback-ban-on-sale-of-plastic-5289089.php.

Laville, Sandra, and Matthew Taylor. 2017. A Million Bottles a Minute: World's Plastic Binge "as Dangerous as Climate Change." The Guardian (June 28).

Laxer, Gordon, and Dennis Soron. 2006. Not for Sale: Decommodifying Public Life. Peterborough, Canada: Broadview.

Lederer, Edith. 2010. “Access to Clean Water Is 'Human Right,' Says U.N.” The Independent (July 30), www.independent.co.uk/news/world/politics/access-to-clean-water-ishuman-right-says-un-2039083.html.

Liddle, Elisabeth S., Sarah M. Mager, and Etienne L. Nel. 2014. "The Importance of CommunityBased Informal Water Supply Systems in the Developing World and the Need for Formal Sector Support.” The Geographical Journal. doi:10.1111/geoj.12117.

Lobina, Emanuele, Philipp Terhorst and Vladimir Popov. 2011. "Policy Networks and Social Resistance to Water Privatization in Latin America." Procedia Social and Behavioral Sciences 10:19-25.

Loftus, Alex. 2009. "Rethinking Political Ecologies of Water." Third World Quarterly 30 (5):953-968. 
Mack, Elizabeth A. and Sarah Wrase. 2017. "A Burgeoning Crisis? A Nationwide Assessment of the Geography of Water Affordability in the United States." PLoS One 12(1). Doi:10.1371/journal.pone.0169488.

Malkin, Elisabeth. 2012. "Bottled-Water Habit Keeps Tight Grip on Mexicans." New York Times (July 17), www.nytimes.com/2012/07/17/world/americas/mexicans-struggle -to-kick-bottled-water-habit.html.

Marx, Karl. 1867. Capital: A Critique of Political Economy. Chicago, IL: Charles H. Kerr \& Co.

McDonald, David A. 2016. "To Corporatize or Not to Corporatize (and If So, How?)." Utilities Policy 40:107-114.

Mehta, Lyla, Jeremy Allouche, Alan Nicol, and Anna Walnycki. 2014. "Global Environmental Justice and the Right to Water: The Case of Peri-Urban Cochabamba and Delhi." Geoforum 54:158-166.

Mehta, Lyla. 2016. "Why Invisible Power and Structural Violence Persist in the Water Domain." IDS Bulletin 47(5):31-42.

Mercille, Julien and Enda Murphy. 2015. "Conceptualising European Privatisation Processes after the Great Recession." Antipode 48(3):685-704.

Miller, DeMond Shondell and Nyjeer Wesley. 2016. "Toxic Disasters, Biopolitics, and Corrosive Communities: Guiding Principles in the Quest for Healing in Flint, Michigan.” Environmental Justice 9(3):69-75.

Milman, Oliver. 2016. "Millions Exposed to Dangerous Lead Levels in US Drinking Water, Report Finds.” The Guardian (June 28), www.theguardian.com/environment/2016/ jun/28/lead-drinking-water-level-nrdc-report-flint-crisis.

Narain, Vishal. 2014. "Whose Land? Whose Water? Water Rights, Equity and Justice in a Peri-Urban Context.” Local Environment 19(9):974-989.

Nelson, Paul. 2017. "Citizens, Consumers, Workers, and Activists: Civil Society During and after Water Privatization Struggles.” Journal of Civil Society 13(2):202-221.

NRDC. 1999. Bottled Water: Pure Drink or Pure Hype? Washington, DC: Natural Resources Defense Council.

Oaten, James, and Som Patidar. 2020. Delhi is Facing a Water Crisis. Ahead of Day Zero, the City's Residents Have Turned to the Mafia and Murder. ABC News (February 8). Accessed March 11, 2020, www.abc.net.au/news/2020-02-08/delhi-water-crisisleads-to-mafia-murder-and-mutiny/11931208

O'Reilly, Kathleen. 2011. “"They Are Not of This House': The Gendered Costs of Drinking Water's Commodification." Economic and Political Weekly 46(18):49-55.

Parag, Y., and J. T. Roberts. 2009. "A Battle against the Bottles: Building, Claiming, and Regaining Tap-Water Trustworthiness.” Society \& Natural Resources 22 (7):625-36.

Peck, Jamie. 2015. Austerity Urbanism: The Neoliberal Crisis of American Cities. New York: Rosa Luxemburg Stiftung.

Pempetzoglou, Maria and Zoi Patergiannaki. 2017. "Debt-Driven Water Privatization: The Case of Greece.” European Journal of Multidisciplinary Studies 5(1):102-111.

Perreault, Tom. 2013. "Dispossession by Accumulation? Mining, Water and the Nature of Enclosure on the Bolivian Altiplano." Antipode 45(5):1050-1069.

Pierce, Gregory. 2015. "Beyond the Strategic Retreat? Explaining Urban Water Privatization's Shallow Expansion in Low- and Middle-Income Countries." Journal of Planning Literature 30(2):119-131. 
Polanyi, Karl. 1944. The Great Transformation. Boston, MA: Beacon Press.

Pulido, Laura. 2016. "Flint, Environmental Racism, and Racial Capitalism." Capitalism Nature Socialism. 17(3): 1-16. Doi:http://dx.doi.org/10.1080/10455752.2016.1213013.

Ranganathan, Malini and Carolina Balazs. 2015. "Water Marginalization at the Urban Fringe: Environmental Justice and Urban Political Ecology across the North-South Divide." Urban Geography 36:403-423.

Ranganathan, Malini. 2016. "Thinking with Flint: Racial Liberalism and the Roots of an American Water Tragedy." Capitalism Nature Socialism 27(3):17-33.

Rankin, Jennifer and Helena Smith. 2015. "The Great Greece Fire Sale.” The Guardian (July 24), www.theguardian.com/business/2015/jul/24/greek-debt-crisis-great-greecefire-sale

Rector, Josiah. 2016. "Neoliberalism's Deadly Experiment: In Michigan, Privatization and Free-Market Governance Has Left 100,000 People Without Water." Jacobin (October 21), www.jacobinmag.com/2016/10/water-detroit-flint-emergencymanagement-lead-snyder-privatization/.

Roberts, Adrienne. 2008. "Privatizing Social Reproduction: The Primitive Accumulation of Water in an Era of Neoliberalism." Antipode 40(4):535-560.

Robinson, Joanna. 2013. Contested Water: The Struggle Against Water Privatization in the United States and Canada. Cambridge, MA: MIT Press.

Rodwan, John G. 2017. "Bottled Water 2016: No. 1 and Growing: U.S. And International Developments and Statistics." Bottled Water Reporter 57(4) (July/Aug):12-21.

Romano, Sarah T. 2012. "From Protest to Proposal: The Contentious Politics of the Nicaraguan Anti-Water Privatization Social Movement." Bulletin of Latin American Research 31(4):499-514.

Rosemann, Nils. 2005. Drinking Water Crisis in Pakistan and the Issue of Bottled Water: The Case of Nestlé's "Pure Life." Berne, Switzerland: ActionAid.

Ruiters, Greg. 2007. "Contradictions in Municipal Services in Contemporary South Africa: Disciplinary Commodification and Self-Disconnections." Critical Social Policy 27 (4):487-508.

Rushe, Dominic. 2014. "Blow to Detroit's Poorest as Judge Rules Water Shutoffs Can Continue." The Guardian (September 29), www.theguardian.com/world/2014/sep/ 29/detroit-water-shutoffs-legal-judge-bankruptcy-revenue.

Sitisarn, Savarin. 2012. "Political Ecology of the Soft Drink and Bottled Water Business in India; a Case Study of Plachimada." Master's thesis, Lund University.

Sloan, Carrie. 2016. "How Wall Street Caused a Water Crisis in America's Cities." The Nation (March 11), www.thenation.com/article/how-wall-street-caused-a-water-crisis-inamericas-cities/.

Smith, Laila and Susan Hanson. 2003. "Access to Water for the Urban Poor in Cape Town: Where Equity Meets Cost Recovery.” Urban Studies 40(8):1517.

Snitow, Alan, Deborah Kaufman and Michael Fox. 2007. Thirst: Fighting the Corporate Theft of Our Water. San Francisco, CA: Wiley \& Sons.

Spronk, Susan and Jeffery R. Webber. 2007. "Struggles against Accumulation by Dispossession in Bolivia: The Political Economy of Natural Resource Contention.” Latin American Perspectives 34(2):31-47.

Spronk, Susan. 2015. "Roots of Resistance to Urban Water Privatisation in Bolivia: The 'New Working Class', the Crisis of Neoliberalism, and Public Services." pp. 29-51 in Crisis and Contradiction: Marxist Perspectives on Latin America in the Global 
Political Economy, edited by S. J. Spronk and J. R. Webber. Leiden, Netherlands: Brill.

Subramaniam, Mangala and Beth Williford. 2012. "Contesting Water Rights: Collective Ownership and Struggles against Privatization." Sociology Compass 6(5):413-424.

Sultana, Farhana. 2011. "Suffering for Water, Suffering from Water: Emotional Geographies of Resource Access, Control and Conflict." Geoforum 42:163-172.

Sultana, Farhana, and Alex Loftus, eds. 2012. The Right to Water: Politics, Governance, and Social Struggles. London: Earthscan.

Swyngedouw, Erik. 2005. "Dispossessing H2O: The Contested Terrain of Water Privatization." Capitalism Nature Socialism 16(1):81-98.

Swyngedouw, Erik. 2009. "The Political Economy and Political Ecology of the Hydro-Social Cycle.” Journal of Contemporary Water Research \& Education 142(1):56-60.

Szasz, Andrew. 2007. Shopping Our Way to Safety: How We Changed from Protecting the Environment to Protecting Ourselves. Minneapolis, MN: University of Minnesota Press.

Terhorst, Philipp, Marcela Olivera and Alexander Dwinell. 2013. "Social Movements, Left Governments, and the Limits of Water Sector Reform in Latin America's Left Turn." Latin American Perspectives 40:55-69.

The Guardian. 2017. "Jeremy Corbyn's Nationalisation Plans Are Music to Ears of Public." The Guardian (October 1), www.theguardian.com/business/2017/oct/01/jeremycorbyn-nationalisation-plans-voters-tired-free-markets

Transparency Market Research. 2018. "Global Bottled Water Market is Projected to Reach US\$307.2 Billion by 2024.” Press Release (April). Retrieved July 2, 2018 (www .transparencymarketresearch.com/pressrelease/bottled-water-market.htm).

UNDP. 2006. "Human Development Report 2006: Beyond Scarcity: Power, Poverty and the Global Water Crisis." New York: United Nations Development Program.

United Nations. 1992. "Dublin Statement on Water and Sustainable Development." New York: United Nations.

Vail, John. 2010. "Decommodification and Egalitarian Political Economy.” Politics \& Society 38(3):310-346.

Varghese, Shiney. 2007. Privatizing U.S. Water. Minneapolis, MN: Institute for Agriculture and Trade Policy.

Vidal, John. 2006. "Big Water Companies Quit Poor Countries.” The Guardian (March 22), www.theguardian.com/world/2006/mar/22/globalisation.water.

Vilas, Carlos. 2004. "Water Privatization in Buenos Aires." NACLA Report on the Americas 38(1):34-42.

Wait, Isaac W. and William A. Petrie. 2017. "Comparison of Water Pricing for Publicly and Privately Owned Water Utilities in the United States." Water International 42 (8):967-980.

Watts, Jonathan. 2018. "Cape Town Faces Day Zero: What Happens When the City Turns Off the Taps?" The Guardian (February 3), www.theguardian.com/cities/2018/feb/03/ day-zero-cape-town-turns-off-taps.

WHO and UNICEF. 2017. Progress on Drinking Water, Sanitation and Hygiene, 2017. Geneva: World Health Organization and United Nations Children's Fund.

World Bank. 2005. Infrastructure Development: The Roles of the Public and Private Sectors; World Bank Group's Approach to Supporting Investments in Infrastructure. Washington, DC: World Bank. 
Zurita, Maria D. M., Dana C. Thomsen, Timothy F. Smith et al. 2015. "Reframing Water: Contesting H2O Within the European Union." Geoforum 65: 170-178.

Zwarteveen, Margreet Z. and Rutgerd Boelens. 2014. "Defining, Researching and Struggling for Water Justice: Some Conceptual Building Blocks for Research and Action." Water International 39(2):143-158. 